

\section{Safety in the Forests}

Current methods of harvesting wood off hillsides pose a problem in the safe operation of vehicles. Most vehicles in use today can climb slopes of $40 \%$ and greater, but become very unstable when required to cross slopes or turn around on a slope. Many accidents have resulted from this instability.

Recently Go-Tract Systems Limited located near Montreal have introduced a tracked skidder called the "GT 570 Logger" which overcomes this problem. The GT 570 has the same performance when travelling in either direction and has dual controls located fore and aft of the driver. The conventional butt plate has been replaced by a hydraulically operated butt plate which also serves as a blade.

In harvesting operations the vehicle approaches the timber arch or grapple leading, using the butt plate to clear the way when required. The wood is choked or grappled, the driver swivels his seat around to face the direction of travel and drives to the landing using the second set of controls. On reaching the landing the driver again swivels his seat around and faces the direction of the hydraulic butt plate which is in the proper position for stacking.
This concept eliminates the need to turn around and therefore the vehicle can operate in confined spaces. More important, it can travel straight up a $60 \%$ slope, choke or grapple the wood, drive down again without turning around, and does not become unstable. The GT 570 will also operate on side slopes in excess of $40 \%$ when required.

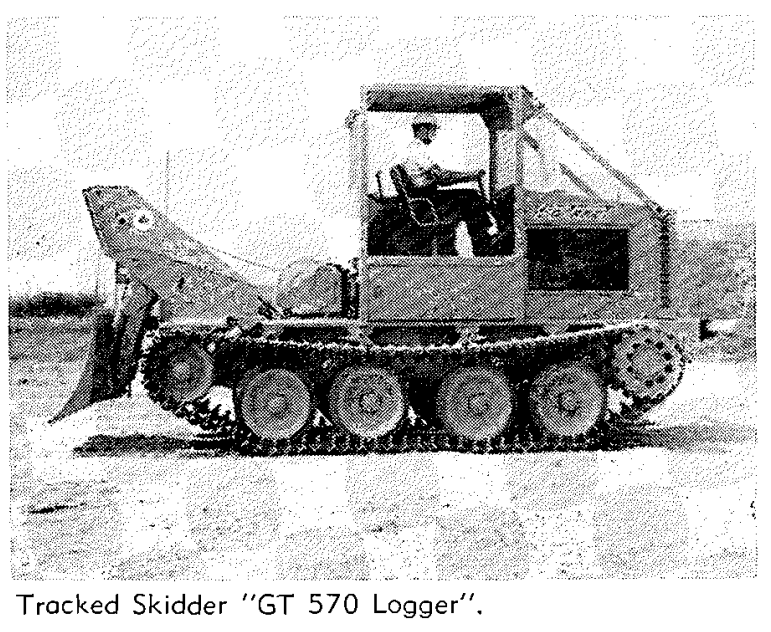




\section{Annosus Root Rot in \\ Eastern Canada}

Damage caused by Fomes annosus (Fr.) Karst in eastern Canada has been recognized at 14 locations in southern Ontario. These are indicated on the accompanying map.

The fungus causes the decay of the roots of many conifers, particularly those of pines (Pinus). Trees with badly diseased root systems often die or are windthrown. Annosus root rot usually enters a stand through the infection of freshly cut stump surfaces. It then spreads to adjacent root systems through root grafts or contacts. Pure stands and plantations are especially susceptible following thinning. Once the disease is established in a stand it is extremely difficult, if not impossible, to eradicate. However, several effective stump treatments have been developed which will protect freshly cut stumps from infection: forest managers should include this preventative measure in all thinnings of conifer stands, especially in ones near areas where damage has occurred. Information is available from the Director, Ontario Region, Department of Fisheries and Forestry, Forest Research Laboratory, Sault Ste. Marie, Ontario. Contributed by H. L. Gross of same address.

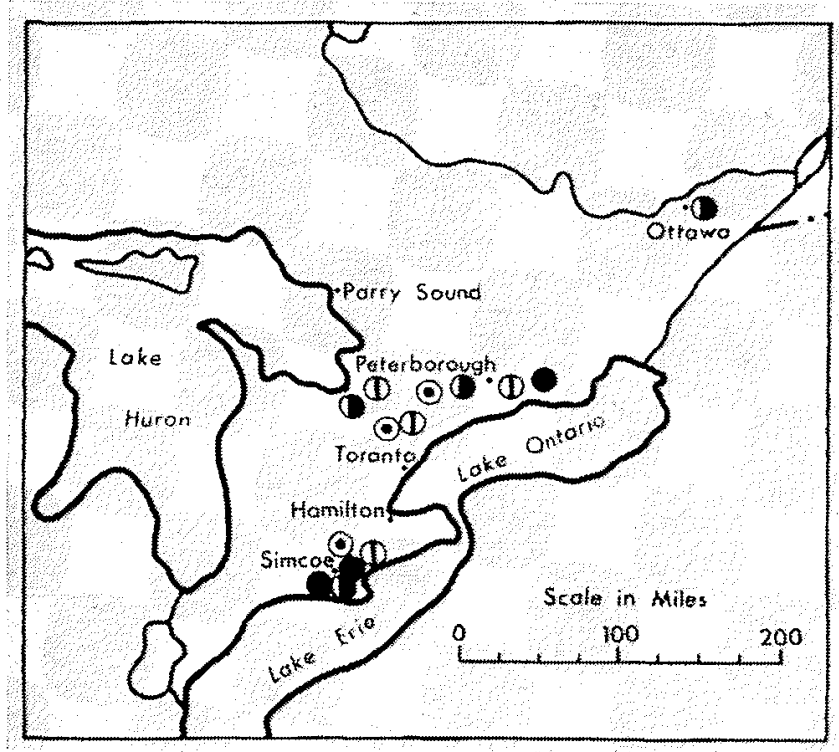

Map showing distribution of annosus root rot in Eastern Canada. The level of damage in 1968 is expressed as a percentage of dead trees or trees showing symptoms of advanced decays, - high (26-100\%), D- moderate (6-25\%), D- light $(2-5 \%), \odot$ - trace $(0-1 \%)$. Spores of the organism ore widely distributed and the disease is expected to spread.

\section{Obituaries}

Herbert William Eades died September 14, 1969 , of a heart condition. He was born in South Shields, England in 1893. He spent his youth at Burton, B.C. and taught school near Nelson, B.C. Served in World War I in the Royal Naval Air Services. Graduated in forestry from University of Washington.

Appointed to Forest Products Laboratory, Vancouver, 1923 as the first forest-products pathologist in western Canada. He worked at the laboratory, which is now part of the federal Department of Fisheries and Forestry, until his retirement in 1960 as head wood pathologist.

He was an authority on wood, best known for his book "Decays and Natural Defects of B.C. Woods" and for his work in drawing up lumber grading rules. His contribution to understanding decay problems of aircraft spruce during World War II was especially valued.

A keen sportsman, he was an early member of the Professional Institute of the Public Service of Canada. He was also a member of the Canadian Society of Forest Engineers and later the Canadian Institute of Forestry and a member of the Canadian Phytopathological Society.

He leaves a wife, son, daughter-in-law and two grandchildren. 